\title{
DEVELOPING ATTITUDE SCALE TOWARDS THE EFFECT OF LISTENING SKILLS OF TALES
}

\author{
Mustafa GAZİOĞLU ${ }^{1}$ \\ Neslihan KARAKUS ${ }^{2}$ \\ 1PhD student, Yildiz Technical University Institute of Social Sciences Turkish Education Department, mustafagazioglu46@gmail.com, \\ ORCID: 0000-0003-0958-1692 \\ ${ }^{2}$ Associate Professor Lecturer, Turkish Education Department, Istanbul, Turkey, avesis.yildiz.edu.tr/nkarakus/, ORCID: 0000-0001-7808-1099
}

Gazioglu, Mustafa, Karakus, Neslihan."Developing attitude scale towards the effect of listening skills of tales: A validity and reliability study”. ulakbilge, 59 (2021 Nisan): s. 493-503. doi: 10.7816/ulakbilge-09-59-01

\begin{abstract}
Listening is among the fundamental language skills that are important in an individual's life. Listening is the fundamental skill that individuals need in communicating with others. Without this skill, it is not possible for an individual to develop social relationships. Listening skill is a fundamental skill that should be acquired from an early age in an individual's life. Listening skill can be acquired through education in individuals. Listening skill is a skill that is aimed to be acquired in Turkish education and training and requires students' cognitive and social competencies such as perceiving, understanding, inferring, interpreting, evaluating and communicating. Tales are thought to contribute to the development of listening skills in children. However, at the fifth grade level, there is no scale that allows examining the effect of fairy tales on listening skill. In this context, it was aimed to develop an attitude scale for fifth grade students to improve the listening skills of fairy tales. The universe of the research consists of 5th grade students studying in Samsun in the 2020-2021 academic year. The sample of the research, on the other hand, consists of 702 students randomly selected from the universe. Analysis of the research data was made using SPSS24 and AMOS26 programs. As a result of the research, "attitude scale towards listening to fairy tales" consisting of five subdimensions and 22 items was developed. The sub-dimensions of the scale were determined as "Attitude Towards Tablela, Understanding, Analyzing, Associating with Life, Presentation of the Tale, Active Participation". The scale was prepared in 5-point Likert type, and the cronbach alpha reliability coefficient for the overall scale was found as , 87 and $47.73 \%$ of the total variance explained in the 5 sub-dimensions.
\end{abstract}

Keywords: Tale, listening skill, attitude, scale 


\section{Introduction}

In today's, expected from education systems is the training of individuals who rather do not store information, than but use it and develop new knowledge (Ozden, 2005). In education, the use of language skills is considered important for individuals to acquire knowledge and skills. Language skills are in the form of listening, speaking, reading and writing, and thanks to these skills, communication can be perfect (Tanaka, Iwasaka, Negoro \& Nakamura, 2020). On the other hand, language skills are based on listening skills (Dogan, 2007).

Listening, which is the basis of education, is perceived as a skill that develops spontaneously, and it is thought that this skill does not need to be trained. However, the education process that starts with listening affects the entire education and social life of the individual (Karatay ve Uzun, 2019). According to researches, a person spends $42 \%$ of the time he / she is with people listening, students listen to teachers and friends for 2.5-4 hours a day at school, also the school success and student's listening ability has corelated (Gunes, 2007; Melanlioglu, 2013). As the importance of listening education increases, there are developments in the mental, spiritual and emotional world of the individual. Because individuals begins to learning with listening. Also listening provides the fundamental for other areas such as speaking, reading, and writing. Children use their listening skills in order to both learn and improve their mental structures. It is easy for students to communicate with listening, learn and develop their mental structure (Ozbay, 2009).

While reading and writing which from the language skills, is generally taught to children with the start of formal education, the acqusition of the listening skill begins in the mother's womb (before birth). So that listening is assumed the basis for other language skills (Gunes, 2014). To effectively develop the listening skill, which continues to develop throughout a person's life, it is important to use some strategies before / during and after listening (Aytan, 2020; Bal, 2018).

There are various types of listening. while the characteristics of listening in some definitions are expressed as "following the text, questioning, creative, passive, participatory, taking notes" (Gunes, 2007), is expressed in some definitions as motivational, sympathy, selective, superficial, active, participatory, critical, passive (passive) features (Ozbay, 2005). In addition, Dogan (2007) classified listening as distinctive, aesthetic, effective, critical, and empathic. These different definitions and classifications related to listening can vary the listening type and strategy of the listener, who is the receiver in the efficient communication, according to the participation in the listening action interactively or non-interactively (Kırbas, 2017).

When the Turkish curriculum is examined, listening is evaluated in two categories as interactive and noninteractive. Interactive Listening is the listening process in which the receiver actively participates in the process of communication, conscious and voluntary throughout the process. Non-interactive listening is the listening process in which the receiver does not react visibly to incoming messages and not active (Gonulal, 2020). Students' not knowing which type of listening to use in the communication process cause to develop a negative attitude towards listening (Yllmaz, 2007). For this reason, the variables in the listening process should be evaluated in detail and correct listening strategies should be taught to students with effective methods.

There are many variables that affect the development of listening skill, which has an abstract feature. Inadequacies in listening skill, which includes a physical and psychological process, can prevent the whole development of other skills (Akyol, 2010). In educational processes, neglecting the listening skill, which is one of the fundamental elements of the language, and giving more importance to other skills negatively affect language development. Spending too much time on reading, writing and speaking skills does not mean that these skills are given importance. On the contrary, not devoting the necessary time to listening skill is negatively affects the development of other skills (Gunes, 2014). Listening is the most important language skill that should be focused on sensitively in the development of individuals' comprehension skills. Critical development of individuals' comprehension skills can be achieved through listening as well as reading (Genc, 2017). Critical listening is in a way the process of checking whether the listeners are correct or not, receiving and interpreting the statements in an effective way. It includes some mental responses such as perception and comprehension (Cihangir, 2004). Listening skill is a skill based on the cognitive and social competencies of students such as perceiving, understanding, making inferences, interpreting, evaluating and communicating, which is aimed to be acquired in Turkish education and teaching (Tabak \& Gocer, 2014).

Throughout history, many different approaches have been put forward in teaching language skills, and there are many methods for gaining fundamental language skills to individuals in today (Kaya, 2014).

Throughout history, many different approaches have been put forward in teaching language skills, and today, there are many methods for gaining fundamental language skills to individuals (Kaya, 2014). It is important to know the strategies before, during and after listening for effective listening. In addition, it is 
necessary to be aware of which type of listening approach should be used according to the subject (Ozudogru, 2019).

In the process of teaching the language in education, narrative texts are important and these narrative texts are used in all language teaching approaches (Akyol, 2010). In addition, since it has an educational and instructive feature, tales are included in the development of listening skill. Tales are generally defined as imaginary stories that involve extraordinary personal events and adventures and are passed down verbally from generation to generation (Kaya, 2014).

In addition to improving the language skills of the children of the tale, on the other hand, it contributes to the development of a solution to their own problems by examining the events in the tale and the situations related to the heroes in their inner world. Tales provide contributions to children such as supporting learning, developing a positive attitude, providing language development, developing mental development and creative thinking, personality development, aesthetics, understanding and stimulating what they are listening (Cetinkaya \& Sonmez, 2019). According to the researches, it is known that tales contribute to the listening skills of children. However, it is seen that studies on tales and listening skills are not at a sufficient level (Bodie, Worthington \& Gearhart, 2013).

There are few researches examining the effect of tales on listening skills. This may be due to the lack of scales prepared for the subject or the insufficiency of existing scale tools in measuring. When the related literature was examined, it was seen that there was no scale prepared for this purpose. Therefore, in this research, aimed to develop a scale to reveal the effects of tales on listening skills.

\section{Purpose}

In this research, it is aimed to develop the tale-listening skills scale to improve the listening skills of middle school 5th grade students.

\section{Research Method and Sample}

\section{Method}

In determining the number of the research group, the "item number*response scale" has been used (Tabachnick \& Field, 2001). So, the research sample size was calculated as minimum 195 student. In order to conduct validity and reliability and analysis of the research 718 volunteer students participated in this research. Tabachnick and Field (2001) evaluated these criteria as "good", 500 people as "very good" and 1000 people as "excellent" in the analysis of the validity and reliability. The distribution of the students in the research group according to the schools is as follows.

Table 1. The Distribution of Students According to Schools in Research

\begin{tabular}{ccc}
\hline Schools & Frequency $(\mathrm{n})$ & Percent $(\%)$ \\
\hline Galip Ozturk Secondary School & 172 & 24 \\
Fatih Secondary School & 122 & 17 \\
Cumhuriyet Secondary School & 67 & 9.3 \\
Milli Irade Secondary School & 72 & 10 \\
Canik Fatih Secondary School & 87 & 12.1 \\
Atakent Secondary School & 127 & 17.6 \\
Atakum Imam Hatip Secondary School & 71 & 9.8 \\
\hline Total & 718 & 100
\end{tabular}

According to Table 1, data were collected from 702 5th grade students studying in Samsun city center and Bafra district in the 2020-2021 academic year. This number is sufficient in terms of factor analysis during the development of the scale. In addition, in the application for confirmatory factor analysis, data were collected from 585 students by determining different samples within the same population. in order to find narrative texts intensely in the curriculum of 
5th grade students, the reserarch group has been selected from 5th graders, and attitudes was evaluated towards the tale listening.

\section{Development Stages of the Scale}

In the development process of the scale, there are processes such as the preparation of the item pool, pilot application, expert opinions, validity and reliability analysis (Bottger, Rudolph, Evanschitzky \& Pfrang, 2017). Similar processes were followed in this research, and these are explained below.

\section{The Preparing of Item Pool}

At the stage of developing the assessment tool to determine the attitudes of middle school 5th grade students towards before, during and after listening, and the strategies they use, firstly the scales about listening at the literature are examined. Items thought to be related to listening skill in the taletelling process were added to the item pool. The grammar and semantic examination of the items was carried out by 6 grammar experts. A total of 40 items were written in the item pool prepared to improve the listening skill of taletelling.

\section{Expert Opinion and Scope Validity}

An item pool of 40 items was created for the "Attitude Questionnaire for Developing the Listening Skills of Tales" (Table 2). The item pool was sent to grammar experts, and 4 items were removed in line with the opinions of the experts. The remaining 36 items were applied to 5 students who were equivalent to the sample group of the research. After the pilot application with the students, 3 items were revised. The detected uncertainties were revised and presented to 5 students again, and it was observed that the items were understandable.

The success of a measurement tool in predicting the behavior of individuals depends largely on its validity and reliability. The adequacy of the scale in terms of internal validity was examined at this stage. Validity is expressed as to what degree a measurement tool accurately measures the variable that it claims to measure. There are three types of validity: scope (content), compliance, and construct validity (Apuke, 2017). Content validity is provided by obtaining expert opinions on whether the measurement tool is suitable for the purpose for which it will be used (Buyukozturk et al., 2017). The content (content) validity of the scale was examined in the research. The items prepared in the research were examined by seven experts, six of them working in Turkish education and one working in the field of assessment and evaluation. The items was examined in terms of style, narrative feature, inclusiveness, strategies and attitudes used before, during and after listening. Corrections were made in terms of content and form in line with the recommendations of experts. After expert opinions, the outline scale was made ready for pilot application. Content validity of the outline scale was tried to be achieved by this method.

\section{Pilot Application}

The items in the outline scale, developed in line with the opinions and suggestions of the experts, were asked to 48 students studying at various schools in Samsun and its districts. Here, the items were examined to be understandable by students and their suitability to listening skills. After this application, arrangements were made in the items by considering the opinions and suggestions of the students about the items of the scale. The scale was prepared with 5point Likert type by the researcher. Items in the tool were scored as 1 (Never Disagree), 2 (Disagree), 3 (Undecided), 4 (Agree), 5 (Strongly Agree). Thus, points were obtained for the data collection tool according to the factors such as attitude towards table, analyzing understanding, associating with life, and interactive participation in listening. The high scores in the sub-dimensions indicate that students use strategies before, during and after listening in Turkish lessons.

\section{Data Analysis}

Regarding the analysis of the data collected in the research, the SPSS 24 program was used to make the exploratory factor analysis of the scale items and to determine the dimensions of the scale. In addition, the analysis of the factor structures and the accuracy of the models obtained as a result of the exploratory factor analysis was carried out using the AMOS26 program. The data of exploratory and confirmatory factor analyzes were collected from the same population and different samples.

\section{Findings}

The data obtained from the students in the research were tested with reliability analysis, exploratory and confirmatory factor analysis. Data regarding the analyzes and findings made in this context are given below.

\section{Exploratory Factor Analysis Results}

The data obtained from 702 students in the research were analyzed with the SPSS 24 program. The stage of the analysis of the data, 16 data, which were determined to be filled randomly or carelessly, were excluded from the 
analysis thanks to the negative items in the scale and the control items. In addition, the scores of the reverse-coded items numbered $14,16,19,21,26,29,32,36$ were reversed with the recode technique. The total scores of the items were taken, and the relationship of each item to the total score was analyzed with reliability analysis. At this stage, items with reliability coefficient values below .30 were removed from the scale (Weaver \& Maxwell, 2014). These items are in the form of 6, 7, 9, 15, 32 and are given in Table 2.

Table 2. Item Correlation Values

\begin{tabular}{|c|c|}
\hline Items & 1.000 \\
\hline 1. While listening to tales, I try to understand the main point of the subject first. & .394 \\
\hline 2. I try to understand the helpful thoughts of the tale that I'm listening to & .381 \\
\hline 3. I try to understand the whole of tale that I am listening. & .367 \\
\hline 4. As I listen to the tale, I try to pull out the plot of the story. & .430 \\
\hline 5. I try to put in my mind the relationships between the person, object, place, time elements and event / events in the tale. & .450 \\
\hline 6. As I listen to the tale, I may guess the rest. & .318 \\
\hline 7. If the thoughts in the tale to become concrete, I understand better it. & .31 \\
\hline 8. While I am listening to the tale, I ask questions about the tale in my mind. & .42 \\
\hline 9. While I am listening to tales, I draw mind maps on a aper. & .21 \\
\hline 10. I try to understand the feelings and thoughts of the people or entities in the tale by putting myself in place. & .50 \\
\hline 11. I try to find different solutions to the problem in the tale I am listen. & .51 \\
\hline 12. I try to use the messages given in the fairy tale in daily life. & .48 \\
\hline 13. Listening to tales has an important place in daily life. & .49 \\
\hline 14. I get bored while listening to story / tale texts. & .53 \\
\hline 15. I think the Turkish lesson would be more enjoyable without fairy tale listening activities. & .31 \\
\hline 16. I don't like long tale texts. & .53 \\
\hline 17. Tale listening activities are fun. & .61 \\
\hline 18. While listening to tales, I feel comfortable myself. & .64 \\
\hline 19. I don't like to listen to tales / stories. & .53 \\
\hline 20. I like doing activities related to the tales I listen to. & .50 \\
\hline 21. I think that tale listening activities are a waste of time. & .54 \\
\hline 22. Time passes very quickly while listening to fairy tales. & .47 \\
\hline 23. While listening to fairy tales, I learn new words. & .51 \\
\hline 24. I believe my imagination flourishes by listening to tales. & .54 \\
\hline 25. I think I am a good listener of tales. & .65 \\
\hline 26. I think it is difficult to understand the tales I listen to. & .38 \\
\hline 27. The topics that are told with the tale / story method is remain in my mind more. & .46 \\
\hline 28. The person's gestural-mimic-tone of voice who tale telling is important. & .39 \\
\hline 29. While listening to tales, I do not like to actively accompany the narrated tale. & .41 \\
\hline 30. I enjoy listening to the rhyme part in tales. & .45 \\
\hline 31. I try to accompany what is told while listening to tales. & .50 \\
\hline 32. Irrelevant thoughts occupy my mind while listening to tales. & .24 \\
\hline 33. I can concentrate my attention while listening to tales / stories. & .56 \\
\hline 34. I try to relate with my life and the tale I listen. & .44 \\
\hline 35. I am impressed by the subject of the tale I am listening. & .53 \\
\hline 36. I do not like to listen to subjects, told in the form of tales / stories. & .53 \\
\hline
\end{tabular}

After the reliability analysis, factor analysis was performed and items were removed from the scale that low factor loadings or seen in more than one factor. In the analyzes performed using factor transformation techniques, it was seen that the most appropriate transformation was represented by the varimax technique in a 5 -factor structure. The items number with $10,11,17,33,24,25,26,18,22$ were removed from the scale during the factor analysis phase.

The variances and reliability coefficient values explained by the sub-dimensions of the scale are given in table 5 . Accordingly, the sub-dimensions and explained variance values were determined as "Attitude Towards Masala 12.96\%, Understanding Analysis 9.96\%, Associating with Life 9.96\%, Presentation of the Fairy Tale $8.27 \%$, Effective Participation $6.56 \% "$. As a result of the reliability and validity processing, it was observed that the scale consists with a 5 -factor structure and 22 items. As a result, KMO sampling adequacy level of the scale is .875 , and explained total variance at the 5 -factor structure $47.73 \%$ (Table 3 ). The factors resulting from the analysis are named. This naming was determined as "Attitude Against Tale, Understanding Analyzing, Associating with Life, Presentation of the Tale, Active Participation" (Table 4). 
Table 3. The Sub-Dimensions of the Scale and the Variance Values Explained

\begin{tabular}{ccccccc}
\hline & \multicolumn{3}{c}{ Initial Eigenvalues } & \multicolumn{3}{c}{ Rotation Sums of Squared Loadings } \\
\cline { 2 - 6 } Component & \multirow{2}{*}{ Total } & \% of Variance & Cumulative \% & \multirow{2}{*}{ Total } & \% of Variance & \multirow{2}{*}{ Cumulative \% } \\
& 5.22 & 23.76 & 23.76 & 2.85 & $\mathbf{1 2 . 9 6}$ & $\mathbf{1 2 . 9 6}$ \\
$\mathbf{1}$ & 1.73 & 7.90 & 31.66 & 2.19 & $\mathbf{9 . 9 6}$ & $\mathbf{2 2 . 9 3}$ \\
$\mathbf{2}$ & 1.29 & 5.87 & 37.54 & 2.19 & $\mathbf{9 . 9 6}$ & $\mathbf{3 2 . 8 9}$ \\
$\mathbf{3}$ & 1.17 & 5.32 & 42.86 & 1.82 & $\mathbf{8 . 2 7}$ & $\mathbf{4 1 . 1 6}$ \\
$\mathbf{4}$ & 1.07 & 4.86 & 47.73 & 1.44 & $\mathbf{6 . 5 7}$ & $\mathbf{4 7 . 7 3}$ \\
$\mathbf{5}$ & & & &
\end{tabular}

In the research, the plot graph of the distribution of the items according to the item eigenvalues obtained by factor analysis is given at the Figure 1.

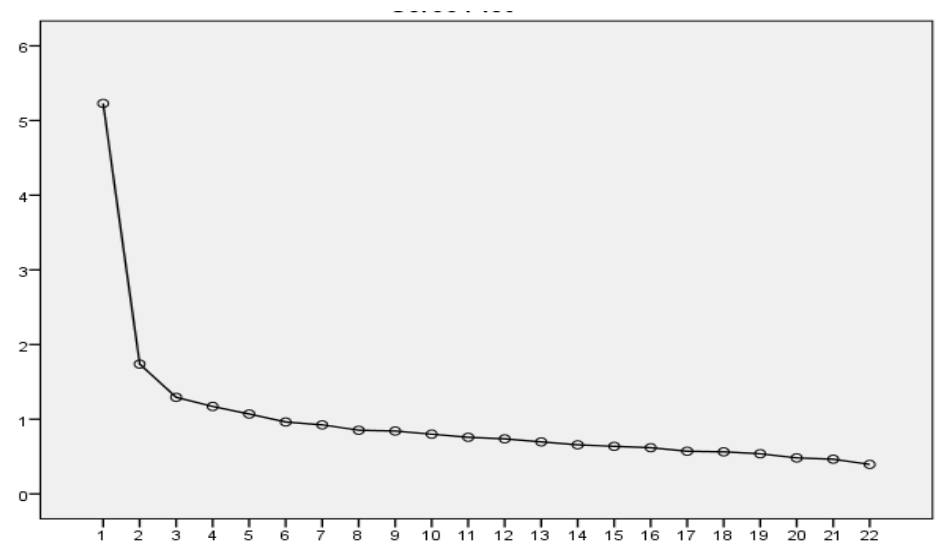

Figure 1. Item Eigenvalues and Plot Analysis

Table 4. Factors and Factor Load Values

\section{Factors}

14. I get bored while listening to story / tale texts.

.76

19. I don't like to listen to tales / stories.

21. I think that tale listening activities are a waste of time.

16. I don't like long tale texts.

36. I do not like to listen to subjects, told in the form of tales / stories.

1. While listening to tales, I try to understand the main point of the subject first.

.60

5. I try to put in my mind the relationships between the person, object, place, time elements and

event / events in the tale.

3. I try to understand the whole of tale that I am listening.

4. As I listen to the tale, I try to pull out the plot of the story.

2. I try to understand the helpful thoughts of the tale that I'm listen

.55

8. While I am listening to the tale, I ask questions about the tale in my mind.

.49

12. I try to use the messages given in the fairy tale in daily life.

34. I try to relate with my life and the tale that I listen.

13. Listening to tales has an important place in daily life.

20. I like doing activities related to the tales that I listen.

23. While listening to fairy tales, I learn new words.

30. I enjoy listening to the rhyme part in tales.

28. The person's gestural-mimic-tone of voice who tale telling is important.

27. The topics that are told with the tale / story method is remain in my mind more.

35. I am impressed by the subject of the tale I am listen.

29. While listening to tales, I do not like to actively accompany the narrated tale. 
In factor analysis, as a result of the transformation of the items according to the factors, the factors and items in the factors are given in Table 5. Accordingly, while the item with the highest factor loading was item " 29 . While listening to tales, I do not like to actively accompany the narrated tale", the lowest factor loading is item "30. I enjoy listening to the rhyme part in tales."

In the research, the values obtained as a result of factor analysis which sub-dimensions, item numbers and Cronbach's Alpha $(\alpha)$ reliability coefficients are given in Table 5. When the reliability coefficient values of the subscales of the scale are examined, it is seen that the reliability scores in all sub-dimensions are highly reliable $(\alpha>, 70)$ (Weaver \& Maxwell, 2014). As a result of the factor analysis, the item correlation values of the 22 items in the scale were examined in Table 6.

Table 5. Reliability Coefficients of the Factors and Explained Variance Values

\begin{tabular}{lcc}
\hline & Number of Items & Cronbach Alpha Values (a) \\
\hline Attitude Against Tale & 5 & .86 \\
Understanding Analyzing & 6 & .78 \\
Associating with Life & 6 & .79 \\
Presentation of the Tale & 3 & .80 \\
Active Participation & 2 & .88 \\
\hline Total & $\mathbf{2 2}$ & $\mathbf{. 8 7}$ \\
\hline
\end{tabular}

When the sub-dimensions of the scale and the correlation values of the items are examined, the lowest item correlation value in the dimension of Associating with Life is "23. While listening to fairy tales, I learn new words." In addition, it is seen that the highest item correlation value belongs to the item "29. While listening to tales, I do not like to actively accompany the narrated tale." in dimension of Active Participation. When evaluated in general, it is seen that the items have medium and high correlation values. These are items with number 6, 7, 9, 15, 32. As a result, 9 items were removed from the scale by factor analysis and 5 items reliability analysis, and the scale was determined as 22 items.

Table 6. Sub-Dimensions of the Scale and Item Correlation Values

\begin{tabular}{|c|c|c|}
\hline & Items & Correlation Values \\
\hline \multirow{5}{*}{ Attitude Against Tale } & 14. I get bored while listening to story / tale texts. & .76 \\
\hline & 16. I don't like long tale texts. & .72 \\
\hline & 19. I don't like to listen to tales / stories. & .75 \\
\hline & 21. I think that tale listening activities are a waste of time. & .70 \\
\hline & 36. I do not like to listen to subjects, told in the form of tales / stories. & .71 \\
\hline \multirow{6}{*}{$\begin{array}{l}\text { Understanding } \\
\text { Analyzing }\end{array}$} & 1. While listening to tales, I try to understand the main point of the subject first. & .63 \\
\hline & 2. I try to understand the helpful thoughts of the tale that I'm listen & .61 \\
\hline & 3. I try to understand the whole of tale that I am listening. & .53 \\
\hline & 4. As I listen to the tale, I try to pull out the plot of the story. & .61 \\
\hline & $\begin{array}{l}\text { 5. I try to put in my mind the relationships between the person, object, place, time } \\
\text { elements and event / events in the tale. }\end{array}$ & .60 \\
\hline & 8. While I am listening to the tale, I ask questions about the tale in my mind. & .62 \\
\hline \multirow{6}{*}{ Associating with Life } & 12. I try to use the messages given in the fairy tale in daily life. & .64 \\
\hline & 13. Listening to tales has an important place in daily life. & .62 \\
\hline & 20. I like doing activities related to the tales that I listen. & .64 \\
\hline & 23. While listening to fairy tales, I learn new words. & .58 \\
\hline & 30. I enjoy listening to the rhyme part in tales. & .57 \\
\hline & 34. I try to relate with my life and the tale that I listen. & .61 \\
\hline \multirow{3}{*}{$\begin{array}{l}\text { Presentation of the } \\
\text { Tale }\end{array}$} & 27. The topics that are told with the tale / story method is remain in my mind more. & .72 \\
\hline & 28. The person's gestural-mimic-tone of voice who tale telling is important. & .72 \\
\hline & 35. I am impressed by the subject of the tale I am listen. & .73 \\
\hline \multirow{2}{*}{ Active Participation } & 29. While listening to tales, I do not like to actively accompany the narrated tale. & .91 \\
\hline & 31. I try to accompany what is told while listening to tales. & .78 \\
\hline
\end{tabular}




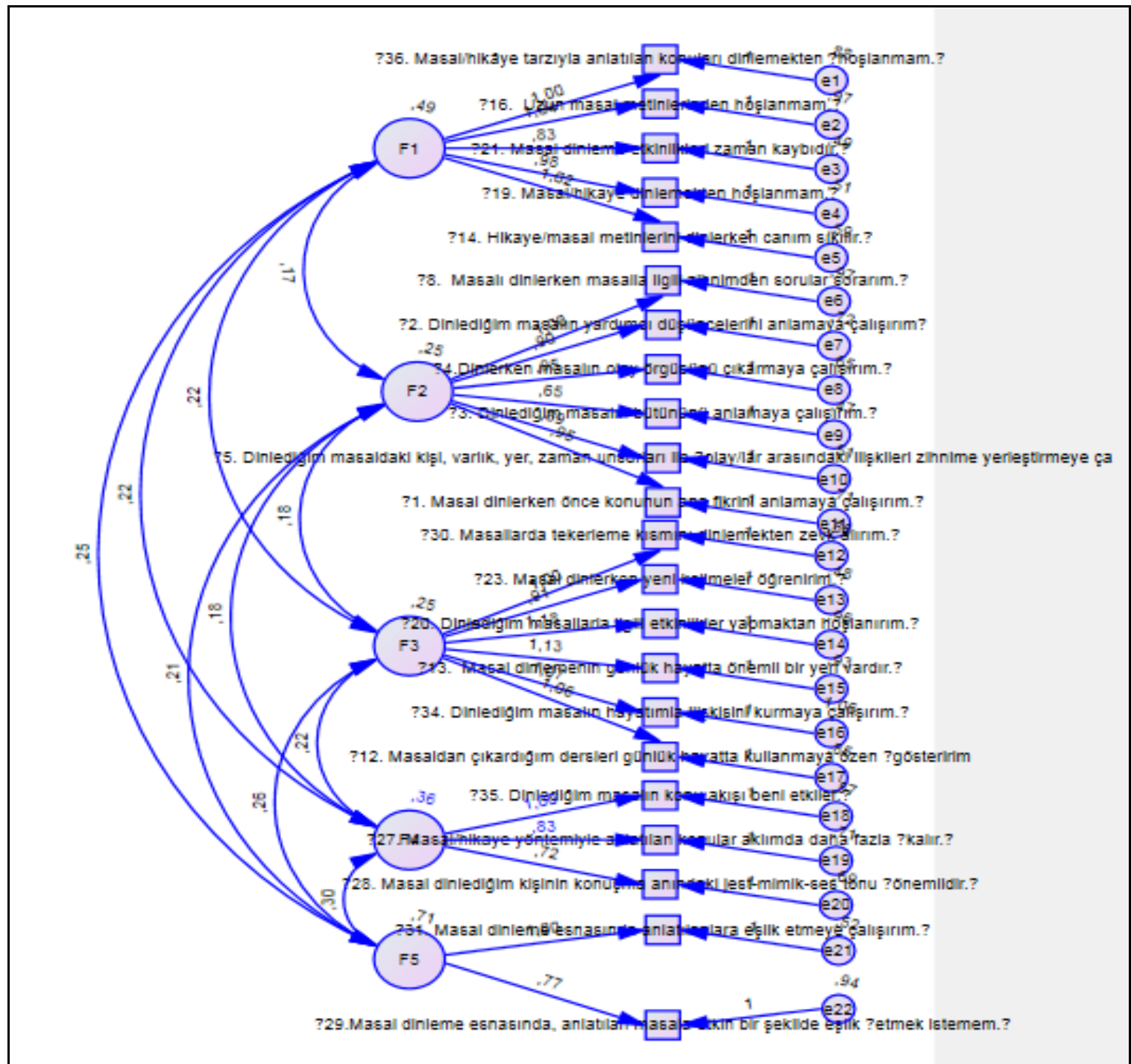

Figure 2. Confirmatory Factor Analysis Model (Path Diagram)

In the research, as a result of the exploratory factor analysis, for the model consisting of 5 factors and 22 items, a confirmatory factor analysis was performed with the data collected from 702 students. This analysis was made in the AMOS26 program. Accordingly, the model was reconstructed and tested with the items associated with each factor. When the values obtained for the model are examined, it is seen that the model is suitable. The values of RMSEA, GFI, AGFI, TLI and CFI in the model show that the model developed in exploratory factor analysis has been validate and suitable (Marsh Guo, Dicke, Parker \& Craven, 2020). When the values of the model at the Table 7 are examined, it is seen that RMSEA (.04), GFI (.95), AGFI (.93), TLI (.90) and CFI (.91).

Table 7. Confirmatory Factor Analysis Results

\begin{tabular}{llllllll}
\hline $\mathbf{N}$ & Number of Item & Number of Factor & RMSEA & GFI & AGFI & TLI & CFI \\
\hline 702 & 22 & 5 & .04 & .95 & .93 & .90 & .91 \\
\hline
\end{tabular}

In addition, as a result of the confirmatory factor analysis, the model (Path Diagram) created for the items in the scale and the sub-dimensions of the scale is given Figure 2. Therefore, It can be said that the model is valid due to the low error variances among the factors in the model. 


\section{Results}

In the research, it is aimed to develop an attitude scale for evaluating the effect of tales on listening skill. For this purpose, an attitude scale was developed to evaluate 5th grade students' tale listening skills. In the development of the scale, firstly, an item pool was prepared in line with the relevant literature and expert opinions. The item pool was examined by experts and a pilot study was conducted to determine the comprehensibility levels of the items by the students. After the pilot implementation, regulations were made at the items. In the preparation of the items of the scale, the 5-point likert (rating) technique was used, and the items were evaluated between Never Disagree and Strongly Agree. Afterwards, the scale was applied to 702 students (5th grade) in schools randomly selected from the universe determined in the research. In the reliability analysis of the scale, items with low reliability coefficients were removed from the scale. These are items with number $6,7,9,15,32$. As a resul t, 9 items were removed from the scale by factor analysis and 5 items reliability analysis, and the scale was determined as 22 items.

After the application, factor analyzes and reliability analyzes were made, and 14 items were removed from the scale. As a result, 22 items remained in the scale, consisting of 5 sub-dimensions. Description was made in accordance with the items in the sub-dimensions of the scale. In this context, the sub-dimensions and cronbach alpha reliability coefficients are as follows: Attitude Against Tale (.86), Understanding Analyzing (.77), Associating with Life (.79), Presentation of the Tale (.80), Active Participation (.87). The Cronbach alpha reliability coefficient for the overall scale was determined to be 87 . The total variance explained by the scale in 5 sub-dimensions was found to be $47.73 \%$. In the confirmatory factor analysis, data from 585 students were collected, and as a result of the analysis, it was determined that the model was suitable. Accordingly, the "attitude scale towards listening to tales" developed for 5th grade students has valid and reliable features.

The "attitude scale towards listening to tales" developed within the scope of the research can be used in determining the attitudes of students in different samples towards tales. This scale, which was developed for 5th grade students in the research, can be applied at different grade levels to test its validity and reliability. In addition, using this scale developed for 5th grade students as a model, attitude scales for listening to tales can be developed to be applied to individuals at different education levels.

\section{Kaynaklar}

Akyol, H. (2010). Turkce ogretim yontemleri. Ankara: PegemA Yayınları

Apuke, O. D. (2017). Quantitative research methods: A synopsis approach. Kuwait Chapter of Arabian Journal of Business and Management Review, 33(5471), 1-8.

Aytan, T. (2020). Etkinliklerle dinleme egitimi. Pegem Akademi Yayıncılık.

Bal, M. (2018). Turkce dersinin 21. Yuzy1l becerileri acısından incelenmesi. Turkish Studies, 13(4), 49-64.

Bodie, G. D., Worthington, D. L. and Gearhart, C. C. (2013). The listening styles profile-revised (LSP-R): A scale revision and evidence for validity. Communication Quarterly, 61(1), 72-90.

Bottger, T., Rudolph, T., Evanschitzky, H., \& Pfrang, T. (2017). Customer inspiration: Conceptualization, scale development, and validation. Journal of Marketing, 81(6), 116-131.

Buyukozturk, S., Cakmak, E. K., Akgun, O. E., Karadeniz, S., \& Demirel, F. (2017). Bilimsel arastirma yontemleri. Pegem Attf İndeksi, 1-360.

Cihangir, Z. (2004). Kisilerarası iletisimde dinleme becerisi. Ankara: Nobel Yayınevi.

Cetinkaya, F. C., \& Sonmez, M. (2019). Masal anlatımının ilkokul 4. sınıf ogrencilerinin konusma prozodilerine etkisi. Yaratici Drama Dergisi, 14(2), 297-308.

Dogan, Y. (2007). Illkogretim ikinci kademede dil becerisi olarak dinlemeyi gelistirme calısmaları. Doktora Tezi. Gazi Universitesi Egitim Bilimleri Enstitusu.

Genc, H. N. (2017). Yabanc1 dil olarak Turkce ogretiminde yazma egitimi baglamında yazım ve noktalama. Dil Dergisi, 168(2), 31-42.

Gonulal, T. (2020). Improving Listening Skills with Extensive Listening Using Podcasts and Vodcasts. International Journal of Contemporary Educational Research, 7(1), 311-320.

Gunes, F. (2007). Ses temelli cumle yontemi ve zihinsel yapllandırma. Ankara: Nobel Yayınc1lık.

Gunes, F. (2014). Turkce ogretimi yaklasimlar ve modeller. Ankara: Pegem Akademi Yayınları. 
Karatay, H., \& Uzun, O. (2019). SECICI dinleme stratejisi ogretimi ile 5. Sinıf ogrencilerinin dinledigini not alma ve ozetleme becerilerinin gelistirilmesi. Milli Egitim Dergisi, 48(1), 9-30.

Kaya, M. F. (2014). Dinleme turleri olceginin Turk kulturune uyarlanmasl, dil gecerligi ve faktor yaplsinin belirlenmesi. Abant İzzet Baysal Universitesi Sosyal Bilimler Enstitusu Dergisi, 14 (3), 321- 340

Kirbas, A. (2017). Effects of Cooperative Learning Method on the Development of Listening Comprehension and Listening Skills. Online Submission, 5(1), 1-17.

Marsh, H. W., Guo, J., Dicke, T., Parker, P. D., \& Craven, R. G. (2020). Confirmatory factor analysis (CFA), exploratory structural equation modeling (ESEM), and set-ESEM: optimal balance between goodness of fit and parsimony. Multivariate behavioral research, 55(1), 102-119.

Melanlıglu, D. (2013). Ortaokul ogrencileri icin dinleme kaygısı olceginin gecerlik ve guvenirlik calısması. Adlyaman Universitesi Sosyal Bilimler Enstitusu Dergisi, (11), 851-876.

Ozbay, M. (2005). Bir dil becerisi olarak dinleme egitimi. Ankara: Akcag Yayınları.

Ozbay, M. (2009). Anlama teknikleri: I.dinleme egitimi. Ankara: Oncu Kitap.

Ozudogru, F. (2019). İlkokul ikinci sınıf ingilizce ogretim programı kapsamında dinleme ve konusma becerilerinin ogretimi. Mehmet Akif Ersoy Universitesi Egitim Fakultesi Dergisi, (42), 189-210.

Tabak, G. \& Gocer, A. (2014). Dinleme becerisine yonelik alternatif olcme ve degerlendirme aracları. Bartın Universitesi Egitim Fakultesi Dergisi, 3(2), 250-272.

Tanaka, H., Iwasaka, H., Negoro, H., \& Nakamura, S. (2020). Analysis of conversational listening skills toward agentbased social skills training. Journal on Multimodal User Interfaces, 14(1), 73-82.

Weaver, B., \& Maxwell, H. (2014). Exploratory factor analysis and reliability analysis with missing data: A simple method for SPSS users. The Quantitative Methods for Psychology, 10(2), 143-152.

Yılmaz, İ. (2007). Turkce ogretiminde dinleme becerisini gelistirmeye yonelik onerilen etkinliklerin degerlendirilmesi. Yuksek lisans Tezi. Nigde Universitesi. 


\title{
MASALLARIN DINLEME BECERISININ GELISTTIRLMESINDEKİ ETKISINE YÖNELIK TUTUM ÖLÇEĞİ GELIŞTİRILMESI
}

\author{
Mustafa Gazioğlu, Neslihan Karakuş
}

ÖZ

Dinleme, bireyin yaşantısında önemli olan temel dil becerileri arasında yer almaktadır. Dinleme bireylerin başkalarıyla iletişim kurmada ihtiyaç duydukları temel beceridir. Bu beceri olmadan bireyin sosyal ilişkiler geliştirmesi mümkün olmamaktadır. Dinleme becerisi bireyin yaşantısında küçük yaşlardan itibaren kazanılması gereken temel bir beceridir. Dinleme becerisi bireylerde eğitim yoluyla kazanılabilmektedir. Dinleme becerisi, Türkçenin eğitim ve öğretiminde kazandırılması hedeflenen ve öğrencilerin algılama, anlama, çıkarımda bulunma, yorumlama, değerlendirme ve iletişim kurma gibi bilişsel ve sosyal yeterliliklerini gerektiren bir beceridir. Masalların çocuklarda dinleme becerilerini geliştirmeye katkı sağladığı düşünülmektedir. Ancak beşinci sınıf düzeyinde masalların dinleme becerisine etkisinin incelenmesine imkân sağlayan ölçek bulunmamaktadır. Bu bağlamda araştırmada beşinci sınıf öğrencilerine yönelik, masalların dinleme becerisinin geliştirilmesine yönelik tutum ölçeğinin geliştirilmesi amaçlanmıştır. Araştırmanın evrenini 2020-2021 eğitim öğretim yılında Samsun ilinde öğrenim gören 5. Sinıf öğrencileri oluşturmaktadır. Araştırmanın örneklemini ise evrenden rastgele olarak seçilen 702 öğrenci oluşturmaktadır. Araştırma verilerinin analizi SPSS 24 ve AMOS 26 programları kullanılarak yapılmıştır. Araştırma sonucunda beş alt boyut ve 22 maddeden oluşan "masal dinlemeye yönelik tutum ölçeği" geliştirilmiştir. Ölçeğin alt boyutları "Masala Karşı Tutum, Anlama Çözümleme, Yaşamla İlişkilendirme, Masalın Sunumu, Etkin Katılım” şeklinde belirlenmiştir. Ölçek 5'li likert türünde hazırlanmış olup, ölçeğin geneline ilişkin cronbach alpha güvenirlik katsayısı ise , 87 ve 5 alt boyutta açıkladığı toplam varyans $\% 47,73$ olarak bulunmuştur..

Anahtar Kelimeler: Masal, dinleme becerisi, tutum, ölçek 